\title{
THE EASTERN PARTNERSHIP - A CHALLENGE FOR THE EU'S SOFT POWER IN INTERNATIONAL RELATIONS
}

\author{
Dr hab. Beata Piskorska \\ John Paul II Catholic University of Lublin \\ Institute of Political Science and International Affairs \\ bpiskorska@kul.pl
}

DOI:10.24193/OJMNE.2018.26.06

\begin{abstract}
:
The main problem analysed by the article is one of the key issues of theory and practice in European studies, the impact of the European Union on its surroundings, mainly eastern neighbours in order to change it in accordance with its own preferences. The analysis has been made based on the specifics of the nature of the European Union, which exploits the resources of soft power understood as the system of values, cultural identity and political activities undertaken towards the Eastern Partnership states. It is an idea launched in May 2009 on the basis of the European Neighbourhood Policy and essentially replicated the main weakness of the ENP, offering too little incentive and support to the partners. Therefore, the main aim will be the analysis of the main assumptions, goals and instruments of the EaP as the principal tool of the European Union's soft power toward the region. Simultaneously, a controversial issue of soft power effectiveness of the European Union has been discussed - identified as its soft power in the activities involving the eastern neighbourhood in the post-Soviet region.
\end{abstract}

Keywords: the European Union, the Eastern Partnership, soft power, Poland, eastern neighbours

It is now ten years (26 May 2008) since Poland and Sweden proposed the Eastern Partnership initiative to the European Union. In 2009, the Eastern Partnership initiative was recognized as an official EU cooperation policy comprising six Eastern European neighbours - Armenia, Azerbaijan, Belarus, Georgia, Moldova and Ukraine. The emergence of the EU Eastern Partnership initiative was primarily determined by the fundamental changes in EU external relations, specifically the 'fatigue' in EU development policy, which made the EU look for alternatives to the Community development policy. Slogans such as 'everything but institutions', 'integration without membership', 'less than integration, but more than 
cooperation' etc. appeared. In other words, in the 'frozen' context of its accession and development policy, the EU started looking for ways to expand its power without extending its institutional boundaries (Kasčiūnas, Šukytè, 2013, pp. 1-2).

A special role in the promotion and development of general eastern policy of the EU known as the eastern dimension of the EU was played by Poland due to geographical proximity and historical ties with the region. The policy of Polish diplomacy was very active on every stage of creation of the EU's eastern policy even before 2004. From the very beginning, Poland treated the eastern dimension of the EU as a change stimulation instrument in Eastern European countries (Piskorska, 2017, pp. 311-315). According to Polish diplomacy, the EU should play the role of a specific transformative power, able to reform and democratize poor and destabilized countries. Over the last decade, the European general discourse around its Eastern neighbourhood states has also been cantered on concepts of Europeanization, integration and reform, since it remains within the EU's most important interests to have stable and prosper countries at its borders.

When the EU launched the Eastern Partnership, it did so with much rhetoric about projecting soft power into Eastern Europe. Soft power is understood in a classic sense as "the ability to get what you want thorough attraction rather than coercion and payment" and "getting others to want the outcomes you want". Then, the EaP is supposedly a medium for such attraction, and for co-opting the eastern neighbours around the EU's agenda (Nye, 1990). The EU also believes in its transformative power over the countries in the Eastern Partnership, which is understood as an ability to transfer norms, values, institutions, practices and public policy instruments, as well as the participation of beneficiary countries in the EU market. Despite the Union's efforts to assist these countries in developing their economic and political environments, the outcome of the ENP has been rather disappointing so far, especially in the sphere of democracy and the rule of law.

The main assumptions of this paper are: firstly, despite a multifaceted crisis, the European Union continues to be a soft power that is able to exert influence on its external environment, so that the peace and democratic processes it desires could take place. Thereby, the policy of soft power that is based on values and practices preferred by the Union rather than on "arguments of force" is the tool for the positioning of the European Union as a regional power, for promoting its image and brand outside its borders. Second, by the outset 
of the Eastern Partnership initiative, the EU attempts to play the role of an ambiguous and influential actor, being able to change the way of thinking and democratize states in the region. Due to the fact that the EU cannot offer them an eventual membership perspective, it pursues 'milieu goals' - of indirectly shaping the external environment by means of diplomacy and soft power. Third, soft power occupies a special position in the policy of the European Union toward the said region. Not only is it reflected at the phase of conceptualization in the approach to the sensitive neighbourhood area, but in its implementation as well. The implementation of such a policy, which also arises out of the lack of well-functioning backing of hard power, manifests itself primarily in the application of non-power and non-compulsory instruments.

The paper attempts to answer a few research questions: What does the term of soft power mean in EU policy? What are the main aims, assumptions, and instruments of the European Union's soft power toward the region? What role does the Eastern Partnership play as an instrument of EU soft power? What is the effectiveness of the EU's soft power in the policy toward Eastern Partnership countries?

\section{Soft power as a theoretical approach to the EU's policy towards Eastern}

\section{Partnership states}

Soft power is treated as dominating theoretical approach and as the main research tool serving as a concept basis or as a starting point for other theories. It boils down to the ability to shape the preferences of the other members of the international system with the use of attracting force, its attractiveness, rather than the application of coercion and force. The author of the term is an American researcher of international relations, J. S. Nye, who introduced it into the literature on the subject in 1990 from the field of international relations, in his work titled Bound to Lead: The Changing Nature of American Power (Nye, 1990a).

Soft power is a manifestation of new tendencies relating to the shaping of the international order. As a result of the changes, the discussion revived on limiting the use of hard power as an instrument of foreign policy while the significance of law and international regimes, i.e. the use of soft power in keeping international security increased. Furthermore, the appearance of soft power is a kind of response of the West to the articulation of a new type of challenges and threats, so-called non-military or asymmetric threats, the most 
Issue no. 26/2018

important being terrorism, cyber terrorism, proliferation of weapons of mass destruction, nationalism, ethnic nationalisms, economic crises, climate change, and organized crime. In the case of the European Union, the soft power approach will make it possible to understand and determine its potential in global politics.

The reason behind my selecting and using the concept of soft power as the main framework for researching the EU's policy toward the Eastern Partnership countries in this article is its specificity allowing it to aptly translate into the manner the European Union functions in the said region. The concept has more capacity and greater elasticity than other theories that identify the role of the European Union in the world, although encompassing within its range similar approaches (civilian and normative power). Furthermore, due to the fact that both the EU's policy in its neighbouring states and the idea of the Eastern Partnership countries itself belong to the sphere of external relations, it is assumed that soft power constitutes a certain way or method of foreign policy, of exposing its qualities/attractiveness but also its interests arising out of such determinants formulated by J.S. Nye as culture, values, and foreign policy that is implemented on their basis. Unlike the concept of civilian (Duchêne, 1972) and normative power (Manners, 2002), until now soft power has not been used as a method for a broader analysis of the EU's policy in the region under discussion.

The assumptions of researching soft power include: a given subject's possibility to use soft instruments of a peaceful, political, diplomatic, and cultural character, i.e. noncoercive means in general terms (a reference to the concept of civilian power) and their use by the subject to influence the outside environment; building on the global catalogue of generally accepted values; promoting democratic values; shaping of the ideological nature of international relations (normative power); using its own civilization attractiveness and stirring the interest in its cultural potential; having an effective foreign policy that is based on generally accepted values.

The soft power of the European Union in the post-Soviet areas takes the form of widely understood political, diplomatic, economic, cultural, and social activities. The EU policy sensu largo includes among others promoting European political, economic, cultural, and civilization standards (so-called power of examples), political cooperation (association agreements), economic cooperation (deep free trade areas), liberalization of a visa regime 
(plans of actions for visa liberalization), promotion of the European culture and development of civil society, as well as mediation and presenting a unified front in conflicts in Eastern Europe. The EU's soft power instruments can, therefore, be treated as a natural and logical supplement of mechanisms that the European Union has been using on the international arena so far.

The specificity of the European Union's policy in the international sphere implies one's adducing to the liberal approach in international studies as a theoretical basis for research. Due to the fact that the aim of the European Union is the democratisation and stabilisation of its neighbouring countries through the use of soft instruments: political, diplomatic, and economic, as well as the policy of conditionality as the primary strategy toward its neighbours and the export of the western model, i.e. the market economy and liberal democracy, the components of the strategy are in line with the liberal theory of international relations.

Despite one's treating soft power as an element of a broader European Union policy in the region, it should be kept in mind that the instruments it uses, inter alia those from among the key projects - the European Neighbourhood Policy and the Eastern Partnership do not belong to the manifestations of soft power only, because soft power is an element of international influence, in other words an element of this organization toward the region of the neighbourhood that is subject to the influence or even rivalry for the sphere of influence with other participants of international relations, primarily Russia. This seems relevant to the theory of international influence proposed by K. J. Holstie (Holstie, 1994). The theory, in turn, refers to other than liberal theoretical approaches, namely realism.

However, as a rule, the European Union is not viewed as a traditional/hard power; however, its transformation is noted, one that consists of departing from promoting only a peace project (manifested in using civil means), and heading toward an entity competing for geopolitical influence. This is evident in reference to the necessity to strengthen soft power with hard power as presented in the EU Global Strategy adopted in June 2016 (Shared Vision, Common Action, 2016). The European Union manages the external area by either letting in 'new territories' or by the European Neighbourhood Policy/Eastern Partnership, though which it strives to create a sphere of influence by deepening economic and political relations with the neighbouring states. Furthermore, it can be assumed that, while wishing to 
ensure security for itself through exporting democratic values, the European Union acts for the stabilization of its neighbours.

\section{The main aims and instruments of the Eastern Partnership - the special role} of Poland

The Eastern Partnership (EaP) established by the European Union and the six Eastern partners: Armenia, Azerbaijan, Belarus, Georgia, Moldova and Ukraine at the Summit of $7^{\text {th }}$ of May 2009 in Prague, represents a specific Eastern dimension of the European Neighbourhood Policy (Council of the European Union, 2009). The ENP, covering sixteen states from two different regions: Mediterranean countries (Communication from the Commission, 2004) and Eastern Europe and Southern Caucasus ones, has been a target of major criticism from the Central European states, mainly Poland ever since it was created in the aftermath of the 2004 enlargement. Poland is the largest Central-European member state and the main initiator of the Eastern Partnership, having the greatest political ambitions in the region and being the most fervent advocate of the EU's Eastern policy.

The idea behind the policy was to support democratic transformation and economic development in the new immediate neighbourhood, while in principle excluding the prospect of further enlargement (Cianciara). The policy outlined in the ENP proposal fuelled disappointment in Central Europe and particularly in Poland. It was then widely believed that, although participation in the ENP did not formally exclude future accession, it did de facto define the frontiers of Europe.

Poland advocated for the development of special relations with eastern neighbours within the framework of the 'ring of friends', covering both the Eastern and the Mediterranean regions. In the Polish view, such a differentiation would have contributed to greater efficiency and EU influence in the eastern region. The Polish non-paper (2003) addressed border management, fighting illegal immigration and organized crime, as well as perspectives for economic integration with the EU single market (Non-paper, 2003). The core of this plan was upheld in the Polish-Swedish proposal for an Eastern Partnership and finally implemented by the Commission in its December 2008 communication (Polish-Swedish Proposal, 2008). This shows the continuity of Polish efforts to the benefit of eastern neighbours. 
The main goal of the EaP, as stipulated in the Joint Declaration, is to create all necessary conditions in order to accelerate political association and also economic integration between the EU and the interested partner countries. The EU has a great interest in seeking stability, better governance and economic development at its Eastern border.

The Eastern Partnership is the most developed political initiative which is associated with a set of activities offering soft cooperation mechanisms. This idea combines both political and diplomatic instruments, cultural and education, economic and financial, but also stability ones in neighbouring states in Eastern Europe. The EU perceives eastern partners through the prism of the ability to strengthen its economic, political and energy security and the realization of its soft power policy.

For those reasons, the EU tries to continue cooperation at political, economic and security levels, while also working towards strengthening good administration, market economy and sustainable development. From the EU's perspective, applying soft power strategy by maintaining of active neighbourhood policy and the stabilization of each dimension of the European security architecture is essential to becoming an important actor in the region.

According to the former president of the European Commission, J. M. Barroso, the Eastern Partnership represents a significant progress in comparison to the European Neighbourhood Policy and reflects a soft power projection in the post-Soviet area (Runner, 2008). This partnership shows what could be called the power of soft power, the ability of the EU to attract others and bring about changes in societies. According to Barroso, "prosperity and stability in the $21^{\text {st }}$ century will be brought about by economics, not by missiles; by political dialogue, not by demonstrations of force”. He also underlined the EU's ambition to transform the post-Soviet countries into Western-type democracies and market economies, hitting a rare note of assertiveness in EU foreign policy vis-à-vis Russia.

Furthermore, as Poland's foreign minister, Radoslaw Sikorski, said, the European Union will not apologize for the “civilizational attraction” of its Eastern Partnership project, a Polish-Swedish initiative that Russia claims is a front for an attempt to secure for the bloc a "sphere of influence" (Polish FM).

The EU's use of its soft power is trying to assist partners in their modernization efforts via their convergence with EU standards and rules. The main objective of the EaP is to 
bring the Eastern partners closer to the EU by exporting the EU acquis and European values into the Union's Eastern neighbourhood. There is also a plan for the development of relations between the Union and the countries of Eastern Europe and South Caucasus, which offers the latter a possibility of gradually joining EU policies and programmes and of integrating with the common market.

As examples of the EU's soft power instruments towards EaP states we can enumerate: association agreements, economic cooperation, financial support and humanitarian aid, public diplomacy (scholarships, student exchange, trainings), civilian missions, support for governments, civil society and democracy.

The main objective was to deepen bilateral cooperation, while promoting more profound integration of all partners with the EU (Wolczuk, 2011, p. 8). At first glance, the EaP does not bring much novelty in institutional terms to bilateral relations between the EU and partner countries. These take place in the context of the established institutional frameworks, i.e. the Partnership and Cooperation Agreements (PCAs). The pivotal innovation of the EaP from the point of view of the partner countries is the development of new ambitious legal frameworks: the Association Agreements (AAs), which were negotiated with the EU by most of the partner countries (Communication from the Commission, 2008a). An integral part of the AA are the agreements on Deep and Comprehensive Free Trade Areas (DCFTA), which include a very detailed set of policy prescriptions, requiring extensive approximation to the acquis (Drăgan, 2015, p. 9-10). Additionally, according to the document, this deepened bilateral cooperation includes a broader migration agenda that encompasses a roadmap towards a visa-free regime and enhanced EU support for sector reform and student and scholar exchange programmes.

The EaP initiated a multilateral format in interactions with post-Soviet states, which share many common legacies but also some essential differences, not least their geography, preferences vis-à-vis the EU and progress of their bilateral relations with the Union. The multilateral cooperation is focused on the following principles: 1) project-orientation; 2) flexible participation in the projects (on a voluntary basis, and depending on the interests of each country); 3) complementarity with the regional projects being developed under the Black Sea Synergy or Northern Dimension (Multilateral Cooperation). The added value of the initiative is its fostering of regional links among partner countries and the enhancement 
offer for Belarus, as well as the possibility it provides to extend certain projects to Russia if the latter is willing to get involved.

The realization of the aims of the EaP will be supported by the flagship initiatives such as the Integrated Border Management Programme; a Small and Medium Enterprises Facility; the promotion of Regional electricity markets, energy efficiency and renewable energy sources, th development of the Southern energy corridor; and cooperation on Prevention of, preparedness for, and response to natural and man-made disasters (The Eastern Partnership). Soft political instruments are also implemented by the existing and developed social structure, starting from regular summits of heads of states or governments to the mobilization all social trends such as Euronest (Parliamentary Assembly of EaP), Civil Society Forum (Eastern Partnership Civil Society Forum), CORELAP and Sopot Business Forum.

The deepening of relations with the EU depends on the partners' progress in implementing such values as democracy, rule of law, upholding human rights and the implementation of the principles of market economy, sustainable development and good governance. At the same time, the EU undertakes to support reform efforts in the neighbouring states. In this context, the comprehensive institution-building programme for improving administrative capacity in all relevant sectors of cooperation will be developed and co-financed through the European Neighbourhood and Partnership Instrument (now, European Neighbourhood Instrument) (Wojna, Duleba, p. 92). Hence, the transformative soft power used towards eastern partners means the ability of the EU to spread democracy and motivate them to reform, but also the strong support of the EU's interests and values in the region.

\section{The effectiveness of the EU's soft power in the policy toward Eastern}

\section{Partnership countries}

The efficiency evaluation of the EU's soft power policy in the region of the six Eastern Partnership countries is not an easy task. This problem is very complex. It depends, firstly, on the specificity of the phenomenon of soft power, the hybrid structure of the EU's foreign policy and the differences between the six Eastern Europe countries. The other determinants are the capabilities and the will of the beneficiaries of the Eastern Partnership to 
adapt to soft actions of the EU. Summing up, ten years of functioning of this initiative (20082018) have proved divergent trends in the future development of the eastern neighbours and in their relations with the EU.

At present, as a result of asymmetry in their adapting to the requirements and drawing closer to the European Union, these countries are divided into 'associated states' (signatories of the affiliation treaties with the European Union - Ukraine, Moldova and Georgia) and those not in favour of integration (Armenia, Azerbaijan, and Belarus).

As a consequence, the $\mathrm{EaP}$ is divided into those countries that signed Association Agreements with the EU and those preferring to maintain their loyalty to Eurasian integration. The first group consists of three states (Ukraine, Moldova and Georgia), willing and able to integrate with the EU within the proposed initiatives. Therefore, the EaP has managed to provide tangible value to the most committed members, such as visa-free travel and trade benefits (Deep Comprehensive Free Trade Agreements), i.e. to three countries which are also proud of their association with the EU through the signed Association Agreements (AAs).

The second group consists of the states which are reluctant to integrating with the EU, and to adapting to its requirements. These are: Armenia, Azerbaijan and Belarus, which are sensitive to the soft and, more recently, hard influence of Russia. It means that the implementation of the Eastern Partnership depends predominantly on the Eastern neighbours' commitment to the project. The level of upholding the rules of democracy, civil rights and liberties, and the rule of law varies among the countries to which the EaP is addressed (Wojna, Duleba, p. 93).

What is the reason for the weak effectiveness of the Eastern Partnership? Firstly, there is a growing feeling that the AA is less relevant than the populations of member states expected. It is not difficult to see the striking clash of views between EU bodies and EaP governments, revealing a serious lack of mutual understanding. EaP states are expected to act as 'accession countries', restricted from accessing EU structural funds and other development money that could greatly improve their economic resilience. History has proved that the perspective of integration was the greatest guarantee of successful internal changes in applicant countries. Unfortunately, the EU is unable to ensure membership for countries of the eastern neighbourhood, even in the long-term perspective. Therefore, the lack of a 
membership perspective makes this policy opaque, since it is not transparent how a policy could otherwise incentivise the neighbours (Kelley, 2006, p. 49). In other words, EaP citizens have yet to see the benefits of membership.

On the other hand, the Eastern Partnership as an initiative focused first of all on the EU exerting its influence as a soft power, it is not a very original response to the security challenges in the Eastern neighbourhood because, in fact, it is a continuation of the ENP, which was launched some years ago. The EU's cooperation with its Eastern neighbours is to lead to the transfer of good EU practices and standards in the fields of trade, economy and politics, and its pace will depend on the changes taking place in those countries, and on the partners' expectations. The hard security issues related to regional conflicts (Ukraine-Russia, Nagorno-Karabakh, Abkhazia, South Ossetia and Transnistria) are not included in the agenda. It needs to be emphasized, however, that without deeper involvement in conflict resolution there, the EU will not be able to achieve its own interests in the Eastern neighbourhood. In this context, the EaP could only play a supporting role, providing a forum for dialogue and instruments for the Europeanization of the six countries (Cornell, Benes, 2009). This may, hypothetically, enable the Union to make full use of its soft power and thereby indirectly contribute to the improvement of international security in the region (Piskorska, 2014, p. 206). However, as an initiative designed to contribute to the transformation of the Eastern neighbours into democratic states with transparent and reliable market economies, the Eastern Partnership could have a strategic significance for the stability and security of both the countries of the Eastern dimension of the ENP and the EU as a whole.

We can unfortunately also notice that despite the initial aim to create a ring of friendly states around the EU, the EaP ended up being perceived as a "ring of fire", which reveals the multiple flaws and ambiguities of the original concept. The strategic resolve to transform the EU's eastern neighbours is not as strong as it once was, while an assertive Russia "flexes its muscles” (Muntenau, 2017).

The half-progress within the Eastern Partnership of the EU is also due to external factors, such as the EU debt and migration crisis or the revolutions in the Southern flank of the ENP which shifted the EU's attention away from its eastern neighbours. Nevertheless, there has been a certain overall progress in the economic sphere of the Eastern 
neighbourhood, namely when it comes to development and growth within the areas of trade, FDI flows or real GPD growth (Sabbati, 2013, p. 3). At the same time, regarding the democratic environment within this region, the evolution is quite backwards (except for Moldova and Georgia) (Sabbati, 2013, p. 4). Most of the regimes have consolidated and centralized their power and the EU's policy in the region has not achieved its expected ambitious objectives since the support for democratic development and good governance represents a priority.

According to the EaP Index (Eastern Partnership Index 2015-2016), Georgia, Moldova and Ukraine are the leaders in legal convergence with the EU, while the remaining three countries (Armenia, Azerbaijan and Belarus) have implemented only limited reforms. The most striking sign of decline is the rising gap between plans for reform and actual results, growing political instability at home, rising external insecurities and foreign military threats. All of this makes the original assumption that EaP states will be able to become a 'well governed ring of friends around EU' extremely optimistic. So far, however, visa liberalisation has been a powerful incentive in pushing for real reform.

The general conclusion that can be drawn from the impact that the EU soft power policy has had on its neighbours is that the pace of progress is determined by the extent to which partners are willing to implement the necessary reforms; not coincidentally, many achievements have been met in the economic sphere, particularly in the field of commerce, and almost none in the areas of governance and democracy.

\section{Conclusions}

The analysis of the EU's soft power policy towards the Eastern Partnership countries has enabled us to verify the research hypotheses. Some of them have been confirmed only partially. Over the last dozen or so years, radical changes have indeed taken place in many countries neighbouring the European Union. One could notice both positive and negative tendencies. The former include reforms initiated by local authorities toward the rule of law, an increase in social justice and accountability, which was the reason for awarding the European Union the Nobel Prize in 2012. It should be kept in mind, however, that the changes did not take place as a result of the European Union's using soft power only, but, rather, they were the effect of the reforms undertaken. 
Although part of the EU's political culture is its conviction on the rightfulness of its actions and the ability to impose its own objectives onto other players, it has not so far found its implementation in all countries of the Eastern Partnership. The realization of the example to follow and the model of the promoter of development and democracy, as well as the provider of assistance, have been partially successful in the case of three countries: Ukraine, Georgia, and Moldova, which upon signing the association agreements and the deep free trade area agreements intensified their works for reform according to the direction shown.

Furthermore, with the continued significance of military force for international security, it would be difficult to have just the soft power of the European Union as the tool for positioning it as a regional power, for promoting its image and brand outside its borders. Therefore, the European Union must progress towards equalising potentials arising from the assumptions of pragmatism. Therefore, it is necessary to maintain balance between idealism and realism and to stress the importance of the latter in order to relaunch the project. The European Union willingly presents itself as a modernist entity that does not require force as a tool to achieve the position of a global player, pointing out to its role as a non-military power - an enlightened guide, a civil and normative power, including a propagator of principles of democracy and good rule, which comprehensively forms the concept of soft power.

However, it seems that the European Union's offer is inadequate to the expectations of some Eastern Partnership countries, which express their willingness to become members of the organization, e.g. Ukraine, Moldova, and Georgia, which ambivalently perceive the realization of the EU's soft power. Moreover, building on the policy addressed to candidate countries or aspirant countries, the European Union does not present an offer to its neighbouring countries that is equally attractive. The EU's enlargement policy requirements toward Eastern European countries do not coincide with its proposal addressed to the states which already aspire to become EU member states. The lack of a precise offer can bring about a discouragement of potential candidates and make them turn, again, toward Russia, which would mark a defeat of the EU's eastern policy and the deterioration of the relations therewith (the case of Armenia).

Moreover, due to the lack of any significant involvement, and above all the willingness of member states, the EU has not contributed to stabilizing security in the region, especially in the context of solving the conflicts which exist there. This was proved by the 
hybrid war in Ukraine. Furthermore, it seems that the European Union deliberately, as it were, "turns a blind eye" on the less pleasant events in the world surrounding it and behaves as if the policy of force and geopolitics no longer existed. The conflicts existing in its neighbourhood that have not yet been resolved decidedly exemplify the EU's shortcomings in its effectiveness as a soft power.

Finally, it needs to be stressed that the Eastern Partnership countries form a natural region of soft influence of the European Union but also of other international actors, i.e. Russia, which in recent years has been deliberately applying the tools of soft power without neglecting the hard tools, including the policies of force and energy, at the same time. The research shows that the EU's soft power and attractiveness could be threatened by Russia's activities toward the region. It can weaken the effectiveness and the image of the European Union in the Eastern Partnership countries in the long run. Russia's policy in Ukraine also proves that the geopolitical factor in international relations has been strengthening. This means that, at present, the European Union’s idealistic paradigm is threatened.

\section{Bibliography:}

- $\quad$ CIANCIARA, A.K., The Union for the Mediterranean and the Eastern Partnership: Perspectives from Poland, Czech Republic and Hungary, Report of the Institute of Public Affairs, EuroMesco, p. 8-9.

- $\quad$ Communication from the Commission, 2004, European Neighbourhood Policy Strategy Paper, Brussels, 12 May 2004, COM(2004) 373 final.

- $\quad$ Communication from the Commission, 2008a, Eastern Partnership COM(2008) 823

final, Brussels, 3 December 2008, http://eur-lex.europa.eu/LexUriServ/LexUriServ.do ?uri=COM:2008:0823:FIN:E N:PDF, [accessed on: 15.04.2018].

- $\quad$ DRĂGAN, G., 2015, Deepening the Economic Integration in the Eastern Partnership: from a Free Trade Area to a Neighbourhood Economic Community?, Eastern Journal of European Studies, No. 2, Vol. 6, p. 9-10.

- The Eastern Partnership - Flagship Initiatives, http://eeas.europa.eu/eastern/ initiatives/index_en.htm, [accessed on: 12.04.2018]. 
- CORNELL, S., BENES, K., 2009, "Unresolved Conflicts and Eastern Partnership” a paper submitted by the Institute for Security and Development Policy, Policy Recommendation for Eastern Partnership Summit formulated by participants of workshops of the conference "Eastern Partnership: Towards Civil Society Forum", http://www.pism.pl/zalaczniki/poli- cy_recommendations.pdf, [accessed on: 22.04.2018].

- Declaration by the European Council on the Eastern Partnership, Brussels European Council, Presidency Conclusions, Annex 2, 19-20 March 2009, https://www.consilium.europa.eu/uedocs/cms_data/docs/pressdata/en/ec/106809.pdf., [accessed on: 10.04.2018].

- $\quad$ DUCHÊNE, F., 1972, Europe’s Role in World Peace, [in:] Europe Tomorrow: Sixteen Europeans Look Ahead, ed. by R.J. Mayene, London.

- $\quad$ Eastern Partnership Index 2015-2016, Charting progress in European integration, democratic reforms and sustainable development, December 2017, http://www.eapindex.eu/sites/default/files/EaP_Index_2015-16_0.pdf, [accessed on: 2.03.2018].

- Eastern Partnership Civil Society Forum Concept Paper, http://eeas.europa.eu/eastern/civil_soci-ety/docs/concept_en.pdf, [accessed on: 22.03.2018].

- $\quad$ HOLSTI, K. J., 1994, International Politics: A Framework for Analysis, London.

- Joint Declaration of the Prague Eastern Partnership Summit Prague, Council of the European Union, 7 May 2009, http://www.consilium.europa.eu/uedocs/cms_Data/docs/ pressdata/en/er/107589.pdf., [accessed on: 31.03.2018].

- $\quad$ KASČIŪNAS, L., ŠUKYTĖ, D., 2013, The future of the EU’s Eastern Partnership challenges and opportunities for Lithuania's foreign policy, Eastern Pulse, Eastern Europe Studies Centre, No. 3, Vol. 48, p. 1-2.

- $\quad$ KELLEY, J., 2006, New Wine in Old wineskins: Promoting political reforms through the New European Neighbourhood Policy, Journal of Common Market Studies, No. 1, Vol. 44, p. 29-55.

- $\quad$ MANNERS, I., 2002, Normative Power Europe: a Contradiction in Terms?, Journal of Common Market Studies, No. 2, Vol. 40. 
- Multilateral Cooperation. Eastern Partnership: Supporting Reforms, Promoting Change, http://eeas.europa.eu/eastern/docs/eastern-multilateral_coop_en.pdf., [accessed on: 7.04.2018].

- $\quad$ MUNTENAU, I., 2017, Under Promise, Over Deliver: Prospects for the EU’s Eastern Partnership in 2018, Emerging Europe, http://emerging-europe.com/voices/promise-deliverprospects-eus-eastern-partnership-2018/, [accessed on: 12.04.2018].

- $\quad$ Non-paper 2003, Non-paper z polskimi propozycjami w sprawie przyszłego kształtu polityki rozszerzonej UE wobec wschodnich sąsiadów, Ministerstwo Spraw Zagranicznych Rzeczypospolitej Polskiej.

- $\quad$ NYE, J. S., 1990, Soft Power, Foreign Policy 1990, No. 80.

- $\quad$ NYE, J. S., 1990a, Bound to Lead: The Changing Nature of American Power, New York.

- $\quad$ PISKORSKA, B., 2014, Impact of Anti-democratic Processes in Eastern Partnership Countries on the European Neighbourhood Policy, Zeszyty Natolińskie, No. 59, p. 206.

- $\quad$ PISKORSKA, B., 2017, Soft power w polityce Unii Europejskiej wobec państw Partnerstwa Wschodniego, Lublin 2017.

- Polish FM: EU Won't Apologize For Being 'Attractive' To Its Neighbors, https://www.rferl.org/a/Polish_FM_EU_Wont_Apologize_For_Being_Attractive_To_Its_Nei ghbors/1623797.html, [accessed on: 14.04.2018].

- Polish-Swedish Proposal, 2008: Eastern Partnership, http://www.enpiinfo.eu/library/ content/polish-swedish-proposal-eastern-partnership., [accessed on: 11.04.2018].

- RUNNER, P., 2008, Brussels to Project „Soft Power” in Post-Soviet Zone, EUObserver, https://euobserver.com/foreign/27228, [accessed on: 16.04.2018].

- $\quad$ SABBATI, G., 2013, The EU's Eastern neighbours, Library of the European Parliament, Brussels, http://libraryeuroparl.wordpress.com/2013/03/19/the-eus-easternneighbours, [accessed on: 1.04.2018].

- $\quad$ Shared Vision, Common Action: A Stronger Europe. A Global Strategy for the European Union's Foreign and Security Policy, June 2016, 
https://europa.eu/globalstrategy/sites/ globalstrategy/files/eugs_review_web.pdf., [accessed on: 4.04.2018].

- WOJNA, B., DULEBA, A., Eastern Partnership: the new EU's response to security challenges in the eastern neighbourhood?, p. 92.

- $\quad$ WOLCZUK, K., 2011, Eastern Partnership: Polish-Swedish proposal, draft as of 23 May 2008, Eastern Partnership Review, No 5, p. 8. http://www.tepsa.eu/docs/draft_proposal_eastern_partnership.pdf, [accessed on: 5.04.2018]. 